\title{
GAMBARAN PENGETAHUAN MASYARAKAT PEKALONGAN TENTANG COVID-19
}

\author{
Izzatun Nidaa \\ UPTD Puskesmas Siwalan, Kabupaten Pekalongan \\ email: izzatun.nidaa@gmail.com
}

\begin{abstract}
In early 2020, the world community was shocked by the emergence of Coronavirus Disease 2019 (Covid-19). Common signs and symptoms of Covid-19 infection include acute respiratory symptoms such as fever, cough and shortness of breath. Until now, a vaccine has not been found to prevent Covid-19, so prevention efforts are the first steps that can be taken to prevent the spread of Covid-19 infection. This study aims to obtain an overview of the Pekalongan community's knowledge about Covid-19 and describe an overview of public opinions regarding health promotion about Covid-19 carried out by the Primary Health Care (puskesmas). This research uses descriptive quantitative research methods with cross sectional design. The data collection method uses an online questionnaire via Google Form. Data collection was carried out on 7-10 June 2020. From the results of the study, it was found that most respondents (72\%) had a good level of knowledge about Covid-19. Most of them (70\%) received information about Covid-19 from online media, and $27 \%$ from TV. Most respondents $(60 \%)$ have never received information about Covid-19 from the nearest puskesmas. Most of the respondents felt the need (32\%) and very need (61\%) for education about Covid-19 from the puskesmas. Most of the respondents (77\%) expect the health promotion about Covid-19 from the puskesmas through health education by puskesmas officers. For the health sector, especially the Health Office (Dinas Kesehatan) through the local puskesmas, it is hoped that there will be health promotion activities about Covid-19 to the community through health education by puskesmas officers.
\end{abstract}

Keywords: Knowledge, virus, Covid-19, pandemic

\section{PENDAHULUAN}

Awal tahun 2020, masyarakat dunia dikagetkan dengan kemunculan penyakit Coronavirus Disease 2019 (Covid-19). Pada tanggal 30 Januari 2020 WHO menetapkan Covid-19 sebagai kedaruratan kesehatan masyarakat yang meresahkan dunia. Penambahan jumlah kasus Covid-19 berlangsung cukup cepat dan sudah terjadi penyebaran antar negara. Sampai tanggal 14 Mei 2020, total kasus terkonfirmasi Covid-19 di dunia mencapai 4.248.389 kasus dan kasus kematian berjumlah 294.046 (CFR 6,9\%) di 215 Negara Terjangkit (Kementerian Kesehatan RI, 2020).

Covid-19 muncul pertama kali di Indonesia pada tanggal 2 Maret 2020, dengan adanya laporan kasus terkonfirmasi Covid-19 sebanyak dua kasus di Depok, Jawa Barat. Sampai dengan tanggal 14 Mei 2020, di Indonesia terdapat 16.006 kasus terkonfirmasi
Covid-19 dari seluruh provinsi dan telah terjadi transmisi lokal (Kementerian Kesehatan RI, 2020).

Di Jawa Tengah, kasus Covid-19 pertama dilaporkan di Kota Surakarta pada bulan Maret 2020. Kasus Covid-19 pertama di Kabupaten Pekalongan berjumlah tiga kasus, dilaporkan pada tanggal 9 April 2020 (Kompas.com, 2020). Berdasarkan laman resmi Tim Gugus Tugas Penanganan Covid-19 Kabupaten Pekalongan, sampai dengan tanggal 13 Mei 2020, ada delapan kasus positif, dengan rincian dua orang dirawat, empat kasus sembuh, satu meninggal dunia, dan satu orang menjalani isolasi mandiri. Sedangkan menurut keterangan Wakil Walikota Pekalongan, sampai dengan tanggal 13 Mei 2020, total pasien terkonfirmasi Covid-19 di Kota Pekalongan ada 14 orang, dengan rincian satu pasien dirawat di RSUD Bendan, lima orang menjalani karantina mandiri, enam orang dinyatakan sembuh, dan 
dua orang meninggal dunia (Tribunnews.com, 2020).

Sampai saat ini, belum ditemukan vaksin untuk mencegah Covid-19, sehingga upaya pencegahan adalah langkah awal yang dapat dilakukan untuk mencegah penyebaran infeksi Covid-19. Langkah-langkah pencegahan yang dapat dilakukan antara lain melalui cuci tangan secara teratur menggunakan sabun dan air bersih, menerapkan etika batuk dan bersin, menghindari kontak secara langsung dengan ternak dan hewan liar, serta menghindari kontak dengan siapapun yang menunjukkan gejala penyakit pernapasan seperti batuk dan bersin. Langkah-langkah social distancing dan physical distancing juga diperlukan yaitu menghindari kerumuman dan menjaga jarak dengan orang lain minimal satu meter. Penggunaan masker setiap ke luar rumah juga direkomendasikan oleh WHO sebagai langkah pencegahan Covid-19.

Dalam situasi pandemi seperti ini, pengetahuan masyarakat terkait Covid-19 sangat diperlukan untuk mencegah terjadinya penularan dan penyebaran Covid-19. Pengetahuan masyarakat tentang Covid-19 dapat diperoleh dari berbagai sumber, antara lain TV, media online, media cetak, dan dari petugas kesehatan (Ganing, 2020).

Sesuai dengan Permenkes RI No. 43 Tahun 2019 tentang Pusat Kesehatan Masyarakat, Puskesmas bertanggung jawab atas kesehatan masyarakat di wilayah kerjanya pada satu atau bagian wilayah kecamatan. Puskesmas adalah fasilitas pelayanan kesehatan tingkat pertama yang menyelenggarakan Upaya Kesehatan Masyarakat (UKM) dan Upaya Kesehatan Perseorangan (UKP) dengan lebih mengutamakan upaya promotif dan preventif, salah satunya melalui kegiatan promosi kesehatan.

Berdasarkan hal-hal tersebut, penelitian ini bertujuan untuk memperoleh gambaran pengetahuan masyarakat Pekalongan tentang Covid-19 serta gambaran pendapat masyarakat terkait promosi kesehatan tentang Covid-19 yang dilakukan oleh puskesmas. Hasil penelitian ini diharapkan dapat bermanfaat bagi sektor kesehatan, khususnya Dinas Kesehatan melalui puskesmas, dalam melakukan promosi kesehatan tentang Covid-19 kepada masyarakat.

\section{TINJAUAN PUSTAKA}

Covid-19 adalah penyakit jenis baru yang belum pernah diidentifikasi sebelumnya pada manusia. Virus penyebab Covid-19 dinamakan Sars-CoV-2. Virus corona adalah zoonosis (ditularkan antara hewan dan manusia). Akan tetapi, hewan yang menjadi sumber penularan Covid-19 hingga saat ini belum diketahui. Tanda dan gejala umum infeksi Covid-19 antara lain gejala gangguan pernapasan akut seperti demam, batuk dan sesak napas. Pada kasus Covid-19 yang berat dapat menyebabkan pneumonia, sindrom pernapasan akut, gagal ginjal, dan kematian (Kementerian Kesehatan RI, 2020).

Berdasarkan bukti ilmiah, Covid-19 dapat menular dari manusia ke manusia melalui percikan batuk/bersin (droplet). Orang yang paling berisiko tertular penyakit ini adalah orang yang kontak erat dengan pasien Covid19, antara lain keluarga yang tinggal serumah, rekan kerja sekantor, serta tenaga kesehatan yang merawat pasien Covid-19.

Perilaku kesehatan seseorang dipengaruhi oleh beberapa faktor, baik dari dalam maupun dari luar diri seseorang tersebut. Faktor yang menentukan atau membentuk perilaku tersebut disebut determinan. Menurut Notoatmodjo (2010), perilaku kesehatan seseorang ditentukan oleh 3 faktor utama, yaitu faktor predisposisi (predisposing), faktor pemungkin (enabling), dan faktor penguat (reinforcing).

a) Faktor Predisposisi (predisposing)

Faktor predisposisi adalah faktor-faktor yang dapat mempermudah terjadinya perilaku pada diri seseorang atau masyarakat. Faktor ini antara lain pengetahuan dan sikap seseorang atau masyarakat terhadap apa yang akan dilakukan. Selain itu, kepercayaan, tradisi, sistem, nilai di masyarakat setempat juga dapat mempermudah atau mempersulit terjadinya perilaku seseorang.

b) Faktor Pemungkin (enabling)

Faktor pemungkin adalah faktor pendukung perilaku seseorang. Faktor pemungkin dapat berupa fasilitas, sarana, 
prasarana yang mendukung atau memfasilitasi terjadinya perilaku seseorang. Dari segi kesehatan masyarakat, agar masyarakat mempunyai perilaku sehat harus memiliki akses ke fasilitas pelayanan kesehatan, termasuk kemampuan ekonomi seseorang untuk mengakses pelayanan kesehatan.

c) Faktor Penguat (reinforcing)

Pengetahuan, sikap, dan fasilitas yang ada kadang-kadang tidak menjamin terjadinya perilaku seseorang. Faktor penguat misalkan pesan-pesan dari tokoh masyarakat atau tokoh agama, peraturan, undang-undang dan surat keputusan dari pejabat pemerintahan.

Pengetahuan sebagai salah satu faktor predisposisi merupakan faktor awal yang dapat mempengaruhi perilaku kesehatan seseorang. Pengetahuan adalah hasil penginderaan manusia atau hasil tahu seseorang terhadap suatu objek dari indera yang dimilikinya (Notoatmodjo, 2010). Pengetahuan masyarakat mengenai Covid-19 adalah pemahaman masyarakat tentang penyebab Covid-19, gejala umum, penularan, dan pencegahannya.

\section{METODE PENELITIAN}

Penelitian ini menggunakan metode penelitian deskriptif kuantitatif, dengan desain studi cross sectional. Metode penelitian deskriptif mendeskripsikan distribusi penyakit pada populasi berdasarkan karakteristik dasar individu, seperti umur, jenis kelamin, pekerjaan, kelas sosial, status perkawinan, tempat tinggal dan sebagainya. Desain studi cross-sectional berguna untuk mendeskripsikan penyakit dan paparan pada populasi pada satu titik waktu tertentu. Akan tetapi, desain cross sectional tidak dapat menggambarkan hubungan sebab akibat dan hanya potret sesaat dari suatu masalah kesehatan (Murti, 2013).

Teknik pengambilan sampel penelitian ini adalah insidental atau aksidental (insidental sampling atau accidental sampling). Teknik tersebut adalah pengambilan sampel yang dilakukan atas dasar seadanya tanpa direncanakan terlebih dahulu. Oleh karena itu, data dari hasil teknik sampel insidental tersebut tidak dapat digeneralisasi pada populasi (Rinaldi, 2017).

Dalam masa pandemi Covid-19, pengumpulan data penelitian ini menggunakan kuesioner online dengan Google Form yang disebarkan melalui media sosial. Kuesioner tersebut menggunakan pertanyaan-pertanyaan tertutup. Pengumpulan data dilakukan pada tanggal 7-10 Juni 2020.

Kriteria responden penelitian adalah orang yang tinggal di Kota/Kabupaten Pekalongan minimal enam bulan terakhir dan bersedia menjadi responden. Responden penelitian berjumlah 132 orang. Setelah dilakukan cleaning data, terdapat 10 data yang tidak lengkap atau tidak memenuhi syarat, sehingga didapatkan hasil akhir 122 responden.

Variabel penelitian antara lain umur, jenis kelamin, pekerjaan, pendidikan, lokasi tempat tinggal, serta pengetahuan tentang Covid-19. Pengetahuan masyarakat diukur dengan pertanyaan seputar Covid-19, antara lain penyebab Covid-19, gejala umum, penularan, pencegahan, kelompok berisiko, etika batuk/bersin, rapid test, swab test dan lain-lain. Setiap pernyataan mendapat nilai 1 untuk jawaban yang benar dan nilai 0 untuk jawaban yang salah. Jawaban dari pertanyaanpertanyaan tersebut dikategorikan menjadi tiga kelompok tingkat pengetahuan, yaitu tingkat pengetahuan baik (total skor 22-32), tingkat pengetahuan sedang (total skor 11-21) dan tingkat pengetahuan kurang (total skor <11). Selain itu, penelitian ini juga mencoba menggambarkan tentang informasi seputar Covid-19 yang diperoleh masyarakat dari berbagai media dan pendapat masyarakat terkait promosi kesehatan tentang Covid-19 yang dilakukan oleh Puskesmas setempat.

Analisis data menggunakan aplikasi Google Spreadsheet dan Microsoft Excel 2016. Analisis data dilakukan secara deskriptif univariat. Analisis univariat bertujuan untuk mendeskripsikan atau menjelaskan masingmasing variabel. Hal ini bertujuan agar variabel tersebut mudah dimengerti. Hasil dari analisis data akan didapatkan berupa proporsi atau persentase dari variabel yang diteliti. (Hastono, 2010). 


\section{HASIL DAN PEMBAHASAN}

Responden pada penelitian ini sebagian besar adalah kelompok usia produktif, yaitu umur 17-45 tahun, berjumlah 113 orang $(92 \%)$. Hanya sedikit responden yang berusia $>45$ tahun (7\%). Hal tersebut sejalan dengan beberapa penelitian sebelumnya yang meneliti pengetahuan masyarakat tentang Covid-19. Pada penelitian Utami (2020), Prihati (2020) dan Yanti (2020), didapatkan bahwa responden yang berusia $>45$ tahun berjumlah lebih sedikit dibandingkan dengan responden usia produktif. Hal tersebut dapat dimungkinkan karena penelitian ini menggunakan kuesioner online, sehingga lebih banyak diakses oleh responden dalam kelompok usia produktif daripada kelompok lanjut usia.

Tabel 1 Distribusi Responden Berdasarkan Umur

\begin{tabular}{ccc}
\hline Umur & Jumlah & Persentase \\
\hline$<17$ tahun & 1 & $1 \%$ \\
$17-45$ tahun & 113 & $92 \%$ \\
$>45$ tahun & 8 & $7 \%$ \\
\hline
\end{tabular}

Responden pada penelitian ini sebagian besar adalah perempuan, yaitu sejumlah 92 orang $(75 \%)$. Hal tersebut sejalan dengan penelitian Utami (2020), Ali (2020), dan Hanafiah (2020), bahwa responden sebagian besar adalah perempuan. Akan tetapi, berdasarkan hasil penelitian Prihati (2020), jenis kelamin responden tidak memiliki hubungan yang signifikan terhadap perilaku dalam pencegahan Covid-19.

Selisih proporsi responden perempuan dan laki-laki dalam survei ini adalah 25\%. Hal tersebut tidak berarti bahwa proporsi perempuan dan laki-laki pada populasi penduduk Kota dan Kabupaten Pekalongan memiliki selisih yang jauh. Berdasarkan data publikasi BPS tahun 2020, perbandingan proporsi penduduk laki-laki dan perempuan di Kota dan Kabupaten Pekalongan adalah 50\% dan $50 \%$

Tabel 2 Distribusi Responden Berdasarkan Jenis Kelamin

\begin{tabular}{ccc}
\hline Jenis Kelamin & Jumlah & Persentase \\
\hline Laki-laki & 30 & $25 \%$ \\
Perempuan & 92 & $75 \%$ \\
\hline
\end{tabular}

Pekerjaan responden pada penelitian ini beragam. Beberapa pekerjaan yang terbanyak antara lain guru 33 orang (27\%), karyawan swasta 21 orang $(17 \%)$, pelajar/mahasiswa 14 orang $(11 \%)$, sektor informal 14 orang $(11 \%)$ dan ibu rumah tangga 12 orang (10\%). Dari hasil penelitian Prihati (2020), disimpulkan bahwa jenis pekerjaan responden tidak memiliki hubungan yang signifikan terhadap perilaku dalam pencegahan Covid-19.

Tabel 3 Distribusi Responden Berdasarkan Pekerjaan

\begin{tabular}{lcc}
\hline \multicolumn{1}{c}{ Pekerjaan } & Jumlah & Persentase \\
\hline PNS & 11 & $9 \%$ \\
Guru & 33 & $27 \%$ \\
Tenaga Kesehatan & 5 & $4 \%$ \\
Karyawan swasta & 21 & $17 \%$ \\
Pelajar/ Mahasiswa & 14 & $11 \%$ \\
Ibu rumah tangga & 12 & $10 \%$ \\
Sektor informal & 14 & $11 \%$ \\
Wiraswasta & 9 & $7 \%$ \\
Lain-lain & 3 & $2 \%$ \\
\hline
\end{tabular}

Tingkat pendidikan responden pada penelitian ini beragam, mulai dari $\leq$ SMP 1 orang (1\%), SMA 27 orang (27\%), Diploma 16 orang (13\%), S1 72 orang (59\%) dan S1/S3 6 orang $(5 \%)$. Dapat dikatakan bahwa sebagian besar responden memiliki tingkat pendidikan tinggi. Hal tersebut sejalan dengan beberapa penelitian sebelumnya yang meneliti pengetahuan masyarakat tentang Covid-19. Pada penelitian Utami (2020), Yanti (2020), dan Purnamasari (2020), didapatkan bahwa sebagian responden memiliki tingkat pendidikan tinggi (Diploma, Sarjana, maupun Magister).

Berdasarkan penelitian Prihati (2020), didapatkan hasil bahwa terdapat hubungan tingkat pendidikan responden dengan perilaku pencegahan Covid-19. Pendidikan merupakan salah satu faktor yang dapat mempengaruhi tingkat pengetahuan seseorang. Semakin tinggi seseorang menempuh pendidikan, semakin mudah sesorang mendapatkan informasi. Seseorang dengan pendidikan tinggi, maka semakin luas pengetahuannya, termasuk tentang Covid-19. Akan tetapi, hal tersebut dapat dimungkinkan karena penelitian ini menggunakan kuesioner online, sehingga lebih 
banyak diakses oleh responden dengan tingkat pendidikan tinggi daripada responden yang berpendidikan rendah.

Tabel 4 Distribusi Responden Berdasarkan Pendidikan

\begin{tabular}{lcc}
\hline \multicolumn{1}{c}{ Pendidikan } & Jumlah & Persentase \\
\hline$\leq$ SMP & 1 & $1 \%$ \\
SMA & 27 & $22 \%$ \\
Diploma & 16 & $13 \%$ \\
S1 & 72 & $59 \%$ \\
S2 / S3 & 6 & $5 \%$ \\
\hline
\end{tabular}

Hasil penelitian menunjukkan bahwa responden yang bertempat tinggal di Kota Pekalongan sejumlah 71 orang $(58 \%)$ dan responden yang bertempat tinggal di Kabupaten Pekalongan sejumlah 51 orang (42\%). Hal tersebut tidak dapat menandakan perbandingan jumlah penduduk Kota Pekalongan dan Kabupaten Pekalongan. Berdasarkan data publikasi BPS tahun 2020, jumlah penduduk Kabupaten Pekalongan lebih banyak daripada jumlah penduduk Kota Pekalongan.

Tabel 5 Distribusi Responden Berdasarkan Lokasi Tempat Tinggal

\begin{tabular}{lcc}
\hline \multicolumn{1}{c}{ Lokasi } & Jumlah & Persentase \\
\hline $\begin{array}{l}\text { Kota } \\
\text { Pekalongan }\end{array}$ & 71 & $58 \%$ \\
$\begin{array}{l}\text { Kabupaten } \\
\text { Pekalongan }\end{array}$ & 51 & $42 \%$ \\
\hline
\end{tabular}

Berdasarkan kategori tingkat pengetahuan tentang Covid-19, didapatkan $72 \%$ responden memiliki tingkat pengetahuan baik, $26 \%$ responden memiliki tingkat pengetahuan sedang, dan $2 \%$ responden memiliki tingkat pengetahuan kurang. Hal tersebut merupakan awal yang baik untuk mendukung terciptanya perilaku kesehatan yang dapat mencegah Covid-19.

Hasil penelitian ini sesuai dengan beberapa penelitian sebelumnya. Pada penelitian Utami (2020), Prihati (2020), dan Yanti (2020), didapatkan bahwa sebagian besar responden memiliki tingkat pengetahuan baik tentang Covid-19. Berdasarkan penelitian Moudy (2020) dan Purnamasari (2020), terdapat hubungan signifikan antara pengetahuan dengan sikap dan pengetahuan dengan perilaku individu dalam pencegahan Covid-19.

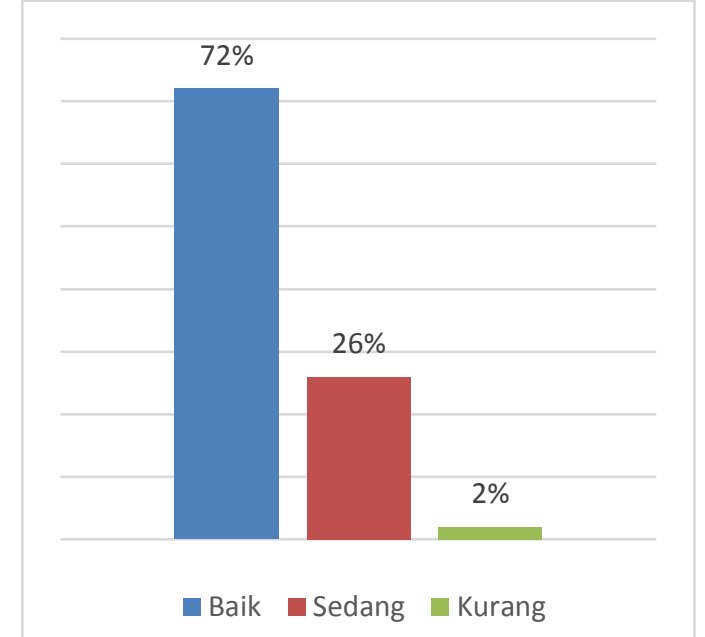

Gambar 1 Distribusi Responden Berdasarkan Tingkat Pengetahuan Covid-19

Dari beberapa pertanyaan terkait Covid-19, sebagian besar responden (98\%) mengetahui bahwa Covid-19 disebabkan oleh virus. Sebanyak $61 \%$ responden mengetahui gejala umum Covid-19, yaitu demam, batuk, sesak nafas. Hal tersebut sesuai dengan penelitian Azlan (2020) di Malaysia, bahwa sebagian besar responden mengetahui gejala umum Covid-19. Walaupun tidak semua kasus Covid19 bergejala tersebut, tetapi gejala umum pada saluran pernafasan adalah gejala awal yang digunakan dalam skrining pasien Covid-19.

Sebanyak $68 \%$ responden mengetahui bahwa saat ini belum ada obat untuk Covid-19. Hal tersebut sesuai dengan penelitian Moudy (2020). Akan tetapi, hanya 39\% responden yang mengetahui bahwa antibiotik tidak dapat mengobati Covid-19. Hasil ini sesuai dengan hasil penelitian Hanafiah (2020) di Malaysia, masih ada $25 \%$ responden yang mengira bahwa antibiotik dapat mengobati Covid-19. Hal tersebut dapat menjadi pertimbangan dalam menentukan tema edukasi kesehatan dari puskesmas setempat.

Sebagian besar responden (98\%) mengetahui bahwa Covid-19 dapat ditularkan dari manusia ke manusia. Sebanyak 91\% responden mengetahui etika batuk/bersin yang benar, yaitu menutup hidung menggunakan bagian dalam lengan atas. Hal tersebut sesuai dengan penelitian Moudy (2020) bahwa etika batuk dan bersin diketahui oleh hampir seluruh responden. Sebanyak $91 \%$ responden 
mengetahui langkah-langkah pencegahan Covid-19, yaitu rajin mencuci tangan dengan sabun, memakai masker saat beraktivitas di luar rumah, menjaga jarak minimal $1-2$ meter dengan orang lain, dan menghindari tempat ramai/kerumunan.

Sebanyak $96 \%$ responden mengetahui bahwa lansia adalah kelompok yang berisiko untuk mengalami sakit yang lebih parah akibat Covid-19. Sebanyak 96\% responden mengetahui bahwa waktu yang diperlukan untuk memutus mata rantai penularan Covid-19 dalam waktu karantina/isolasi mandiri adalah 14 hari. Hal tersebut sesuai dengan penelitian Azlan (2020) di Malaysia, sebagian besar responden mengetahui bahwa lansia adalah kelompok yang berisiko dan sebagian besar responden mengetahui bahwa masa isolasi mandiri adalah 14 hari.

Masih ada beberapa responden (22\%) yang salah memahami bahwa hasil rapid test yang reaktif berarti pasien positif Covid-19. Padahal rapid test adalah skrining awal dalam deteksi Covid-19. Penegakan diagnosa Covid-19 dilakukan dengan swab test. Sebagian kecil responden $(15 \%)$ masih salah memahami bahwa pemakaman PDP/suspek tidak perlu menggunakan protokol pemakaman Covid-19. Hal tersebut dapat dipertimbangkan menjadi tema edukasi kesehatan dari puskesmas setempat.

Dari hasil penelitian diketahui bahwa responden yang memperoleh informasi seputar Covid-19 dari media online sebesar 70\%, dari TV $27 \%$, dari media cetak $2 \%$ dan dari radio $1 \%$. Hal tersebut dapat dimungkinkan karena penelitian ini menggunakan kuesioner online, sehingga hanya diakses oleh responden pengguna internet.

Hal tersebut sesuai dengan penelitian Parikh (2020) di India, bahwa televisi, media sosial, majalah/surat kabar merupakan sumber informasi masyarakat umum dalam meningkatkan pengetahuan tentang Covid-19, dan sebanyak $78.3 \%$ masyarakat umum memperoleh memperoleh informasi seputar Covid-19 dari media online berupa sosial media. Hasil penelitian serupa juga terdapat di di Italia dan Yordania di kalangan siswa sekolah. Kebijakan lockdown memberikan kesempatan yang lebih besar kepada siswa untuk dapat meningkatkan pengetahuan mereka dengan banyak menonton TV dan menjelajah internet (Galle, 2020). Sebagian siswa memperoleh informasi tentang Covid-19 dari internet dan media sosial serta media massa, termasuk TV (Olaimat, 2020).

Tabel 6 Media Informasi Covid-19 yang Diakses Responden

\begin{tabular}{lcc}
\hline \multicolumn{1}{c}{ Media } & Jumlah & Persentase \\
\hline Online & 86 & $70 \%$ \\
TV & 33 & $27 \%$ \\
Cetak & 2 & $2 \%$ \\
Radio & 1 & $1 \%$ \\
\hline
\end{tabular}

Responden yang merasa bahwa informasi yang diperoleh dari beberapa media tersebut sangat jelas sebanyak $10 \%$, jelas $22 \%$, cukup jelas $42 \%$, kurang jelas $22 \%$, dan tidak jelas 4\%. Mengingat sebagian besar informasi Covid-19 didapatkan responden melalui media online, maka dapat dimungkinkan adanya risiko memperoleh pengetahuan yang salah atau hoax. Hingga 5 Mei 2020, hasil pantauan Kominfo menunjukkan 1.401 konten hoax dan disinformasi Covid-19 beredar di masyarakat.

WHO menggunakan kata infodemic sebagai istilah untuk menyebutkan informasi yang melimpah. Informasi yang salah dapat membahayakan kesehatan fisik dan mental seseorang, meningkatkan stigma negatif dan dapat mempengaruhi kepatuhan masyarakat dalam suatu kebijakan kesehatan, sehingga membahayakan kemampuan negara untuk menghentikan pandemi.

Dari hasil penelitian diketahui bahwa sebanyak 73 responden (60\%) menjawab belum pernah memperoleh informasi seputar Covid-19 dari puskesmas terdekat, sedangkan sejumlah 49 responden (40\%) sudah pernah memperoleh informasi seputar Covid-19 dari puskesmas terdekat. Dari $40 \%$ responden yang sudah pernah memperoleh informasi seputar Covid-19 dari puskesmas terdekat, diketahui bahwa mereka yang memperoleh informasi tersebut melalui media cetak/leaflet sebanyak $22 \%$, melalui media online/internet sebanyak $12 \%$, melalui penyuluhan oleh petugas puskesmas sebanyak $31 \%$ dan melalui siaran keliling ambulan sebanyak $35 \%$. 


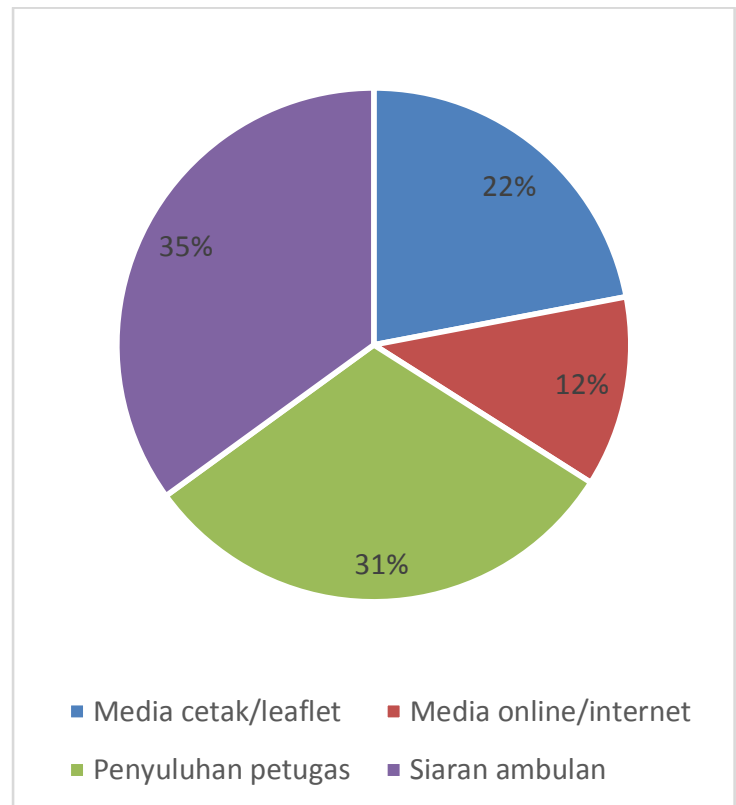

Gambar 2 Gambaran Metode Pemberian Informasi Covid-19 yang Telah Diperoleh dari Puskesmas Terdekat

Terkait pertanyaan apakah puskesmas terdekat memiliki media online atau tidak, sebanyak $72 \%$ responden menjawab tidak tahu, $7 \%$ responden menjawab bahwa puskesmas terdekatnya tidak memiliki media online dan $21 \%$ menjawab bahwa puskesmas terdekatnya memiliki media online. Terkait pertanyaan perlu atau tidaknya puskesmas melakukan edukasi tentang Covid-19 di masyarakat, tidak ada responden yang menjawab tidak perlu atau kurang perlu. Sebanyak $7 \%$ responden menjawab cukup perlu, $32 \%$ responden menjawab perlu, dan $61 \%$ responden menjawab sangat perlu. Hal tersebut menggambarkan bahwa masyarakat membutuhkan informasi tentang Covid-19 dari puskesmas terdekat.

Walaupun sebagian besar responden adalah pengguna media online dan telah memperoleh informasi seputar Covid-19 dari media online, pemberian informasi tentang Covid-19 dari puskesmas yang paling diharapkan oleh responden adalah melalui penyuluhan oleh petugas puskesmas $(77 \%)$. Hal tersebut dapat dimungkinkan karena terlalu banyak informasi yang beredar di media online berupa hoax, sehingga masyarakat lebih membutuhkan penyuluhan langsung dari petugas puskesmas. Hal-hal tersebut dapat menggambarkan kebutuhan masyarakat terkait edukasi kesehatan dari puskesmas tentang Covid-19 dan dapat menjadi dasar bagi puskesmas dalam perencanaan kegiatan terutama program promosi kesehatan.

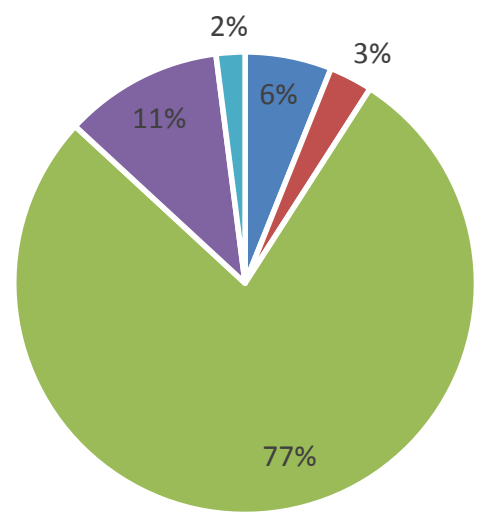

$$
\begin{aligned}
& \text { - Media cetak/leaflet }=\text { Media online/internet } \\
& \text { - Penyuluhan petugas - Siaran ambulan } \\
& \text { - Lain-lain }
\end{aligned}
$$

Gambar 3 Gambaran Metode Pemberian Informasi Covid-19 dari Puskesmas Terdekat yang Diharapkan Responden

Sesuai Petunjuk Teknis Pelayanan Puskesmas pada Masa Pandemi Covid-19, kegiatan Upaya Kesehatan Masyarakat (UKM) tetap dilaksanakan dengan memperhatikan skala prioritas. Kegiatan promosi kesehatan yang perlu dilakukan dalam masa pandemi Covid-19 antara lain meningkatkan literasi serta kapasitas kader, tokoh masyarakat, tokoh agama, kelompok peduli kesehatan agar mendukung upaya penggerakan dan pemberdayaan keluarga dalam pencegahan Covid-19 di wilayah kerja puskesmas. Peningkatan literasi serta kapasitas tersebut dapat dilakukan melalui media online seperti grup Whatsapp atau melalui interaksi langsung dengan memperhatikan protokol kesehatan.

\section{KESIMPULAN DAN SARAN}

\subsection{Kesimpulan}

Dari hasil penelitian ini, didapatkan beberapa kesimpulan sebagai berikut:

a) Sebagian besar responden (72\%) memiliki tingkat pengetahuan baik tentang Covid-19. 
b) Responden yang memperoleh informasi seputar Covid-19 dari media online sebesar $70 \%$, dan dari TV sebanyak $27 \%$.

c) Sebanyak $60 \%$ responden belum pernah memperoleh informasi seputar Covid-19 dari puskesmas terdekat.

d) Sebagian besar responden merasa perlu $(32 \%)$ dan sangat perlu (61\%) adanya edukasi tentang Covid-19 dari puskesmas.

e) Sebagian besar responden $(77 \%)$ mengharapkan pemberian informasi tentang Covid-19 dari puskesmas melalui penyuluhan oleh petugas puskesmas.

\subsection{Saran}

Dari hasil penelitian ini, penulis dapat memberikan beberapa rekomendasi sebagai berikut:

a) Bagi peneliti berikutnya, diharapkan adanya penelitian lebih lanjut tentang hubungan tingkat pengetahuan masyarakat tentang Covid-19 dengan sikap dan perilaku kesehatan masyarakat yang dapat mencegah Covid-19.

b) Bagi sektor kesehatan, khususnya Dinas Kesehatan melalui puskesmas setempat, diharapkan adanya kegiatan promosi kesehatan tentang Covid-19 kepada masyarakat melalui penyuluhan oleh petugas puskesmas.

\section{DAFTAR PUSTAKA}

Ali, S.H., et al. 2020. Social Media as a Recruitment Platform for a Nation Wide Online Survey of Covid-19 Knowledge, Beliefs, and Practices in the United States: Methodology and Feasibility Analysis. BMC Medical Research Methodology. Volume 20. Nomor 116. Halaman 1-11. https://bmcmedresmethodol.biomedcentral.c om/articles/10.1186/s12874-020-01011-0. Diunduh tanggal 2 Desember 2020.

Azlan, A.A., et al. 2020. Public Knowledge, Attitudes and Practices towards Covid-19: a Cross-Sectional Study in Malaysia. PLOS ONE. Volume 15. Nomor 5. Halaman 1-15. https://journals.plos.org/plosone/article?id=1 0.1371/journal.pone.0233668. Diunduh tanggal 2 Desember 2020.
Badan Pusat Statistik Kabupaten Pekalongan. 2020. Kabupaten Pekalongan dalam Angka 2020.

https://pekalongankota.bps.go.id/publication /2020/04/27/d4ce8c572a7e8ce8044818b4/ko ta-pekalongan-dalam-angka-2020.html. Diunduh tanggal 2 Desember 2020.

Badan Pusat Statistik Kota Pekalongan. 2020. Kota Pekalongan dalam Angka 2020. https://pekalongankab.bps.go.id/publication/ 2020/04/27/f20814ce8485dc5adaeccec2/kab upaten-pekalongan-dalam-angka-2020.html. Diunduh tanggal 2 Desember 2020.

Coronavirus Disease (Covid-19) Advice for the Public.

https://www.who.int/emergencies/diseases/n ovel-coronavirus-2019/advice-for-public. Diakses tanggal 14 Mei 2020.

Covid-19 Monitoring System. https://corona.pekalongankab.go.id/. Diakses tanggal 14 Mei 2020.

Gallè, F., et al. 2020. Understanding Knowledge and Behaviors Related to Covid-19 Epidemic in Italian Undergraduate Students: The EPICO Study. International Journal of Environmental Research and Public Health. Volume 17. Nomor 2481. Halaman 1-11. https://www.mdpi.com/1660-

4601/17/10/3481. Diunduh tanggal 2 Desember 2020.

Ganing, A., A. Salim, dan I. Muslimin. 2020. Studi Literatur: Pengetahuan Sebagai Salah Satu Faktor Utama Pencegahan Penularan Covid-19. Jurnal Kesehatan Manarang. Volume 6. Nomor Khusus. Halaman 55 60.

http://jurnal.poltekkesmamuju.ac.id/index.ph $\mathrm{p} / \mathrm{m}$ Oktober 2020. Diunduh tanggal 2 Desember 2020.

Hanafiah, K.M., dan C.D. Wan. 2020. Public Knowledge, Perception and Communication Behavior Surrounding Covid-19 in Malaysia. https://www.researchgate.net/publication/34 0569667 Public knowledge perception an d_communication_behavior_surrounding_C ovid-19 in Malaysia. Diunduh tanggal 2 Desember 2020. 
Hastono, S.P., dan L. Sabri. 2010. Statistik Kesehatan. Rajawali Press. Jakarta.

Kasus Pertama di Pekalongan, 3 Warga Positif Covid-19 Usai dari Bali dan Jakarta. https://regional.kompas.com/read/2020/04/0 9/15350881/kasus-pertama-di-pekalongan-

3-warga-positif-Covid-19-usai-dari-bali-dan. Diakses tanggal 14 Mei 2020.

Kementrian Kesehatan Republik Indonesia. 2019. Peraturan Menteri Kesehatan Republik Indonesia Nomor 43 Tahun 2019 tentang Pusat Kesehatan Masyarakat. Jakarta.

Kementrian Kesehatan Republik Indonesia. 2020. Pedoman Pencegahan dan Pengendalian Coronavirus Disease (Covid19). Revisi ke-4. Jakarta.

Kementrian Kesehatan Republik Indonesia. 2020. Petunjuk Teknis Pelayanan Puskesmas Pada Masa Pandemi Covid-19. Jakarta.

Kominfo Temukan 1.401 Sebaran Isu Hoaks terkait

Covid-19.

https://aptika.kominfo.go.id/2020/05/kominf o-temukan-1-401-sebaran-isu-hoaks-terkaitCovid-19/. Diakses tanggal 15 Mei 2020.

Managing the Covid-19 infodemic: Promoting healthy behaviours and mitigating the harm from misinformation and disinformation. https://www.who.int/news/item/23-09-2020managing-the-Covid-19-infodemicpromoting-healthy-behaviours-andmitigating-the-harm-from-misinformationand-disinformation. Diakses tanggal $15 \mathrm{Mei}$ 2020.

Murti, B. 2013. Desain Studi. Matrikulasi Program Studi Doktoral Kedokteran FKUNS.

https://rossisanusi.files.wordpress.com/2013/ 09/desain-studi.pdf. Diunduh tanggal 5 Desember 2020

Moudy, J., dan R.A. Syakurah. 2020 Pengetahuan terkait Usaha Pencegahan Coronavirus Disease (Covid-19) di Indonesia. HIGEIA Journal of Public Health Research and Development. Volume 4. Nomor 3. Halaman 333-346. http://journal.unnes.ac.id/sju/index.php/higei a/article/view/37844. Diunduh tanggal 2 Desember 2020.
Notoatmodjo, S. 2010. Promosi Kesehatan Teori \& Aplikasi. Edisi Revisi, Rineka Cipta. Jakarta.

Olaimat, A.N., et al. 2020. Knowledge and Information Sources About Covid-19 Among University Students in Jordan: A Cross-Sectional Study. Frontiers in Public Health. Volume 8. Nomor 254. https://www.frontiersin.org/articles/10.3389/ fpubh.2020.00254/full. Diunduh tanggal 2 Desember 2020.

Parikh, P.A., et al. 2020. Covid-19 Pandemic: Knowledge and Perceptions of the Public and Healthcare Professionals. Cureus. Volume $\quad 12 . \quad$ Nomor 5. https://www.cureus.com/articles/31015Covid-19-pandemic-knowledge-andperceptions-of-the-public-and-healthcareprofessionals. Diunduh tanggal 2 Desember 2020.

Prihati, D.R., M.K. Wirawati, E. Supryanti. 2020. Analisis Pengetahuan dan Perilaku Masyarakat di Kelurahan Baru Kotawaringin Barat Tentang Covid-19. Malahayati Nursing Journal. Volume 2. Nomor 4. Halaman 780-790. http://ejurnalmalahayati.ac.id/index.php/man uju/article/view/3073. Diunduh tanggal 2 Desember 2020.

Purnamasari, I., dan A.E. Raharyani. 2020. Tingkat Pengetahuan dan Perilaku Masyarakat Kabupaten Wonosobo tentang Covid -19. Jurnal Ilmiah Kesehatan. Volume 10. Nomor 1. Halaman 33-42. https://ojs.unsiq.ac.id/index.php/jik/article/vi ew/1311. Diunduh tanggal 2 Desember 2020

Rinaldi, S.F., dan B. Mujianto. 2017. Metodologi Penelitian dan Statistik. Pusat Pendidikan Sumber Daya Manusia Kesehatan, Badan Pengembangan dan Pemberdayaan Sumber Daya Manusia Kesehatan, Kementrian Kesehatan Republik Indonesia. Jakarta. http://bppsdmk.kemkes.go.id/pusdiksdmk/w p-content/uploads/2017/11/MetodologiPenelitian-dan-Statistik-SC.pdf. Diunduh tanggal 5 Desember 2020.

Situasi Terkini Perkembangan Coronavirus Disease (Covid-19) $15 \quad$ Mei 2020. 
https://Covid19.kemkes.go.id/situasi-infeksiemerging/info-corona-virus/situasi-terkiniperkembangan-coronavirus-disease-Covid19-15-mei-2020. Diakses tanggal 16 Mei 2020.

Update Virus Corona: Tambah Lagi Satu Pasien Covid-19 di Kota Pekalongan. https://banyumas.tribunnews.com/2020/05/1 3/update-virus-corona-tambah-lagi-satupasien-Covid-19-di-kota-pekalongan. Diakses tanggal 15 Mei 2020.

Utami, R.A., R.E. Mose, dan Martini. 2020. Pengetahuan, Sikap dan Keterampilan Masyarakat dalam Pencegahan Covid-19 di Provinsi DKI Jakarta. Jurnal Kesehatan Holistic. Volume 4. Nomor 2. Halaman 68 77.

http://ejournal.stikesrshusada.ac.id/index.ph $\mathrm{p} / \mathrm{jkh} /$ article/view/85. Diunduh tanggal 2 Desember 2020.

Yanti, B., et al. 2020. Community Knowledge, Attitudes, and Behavior towards Social Distancing Policy as a Means of Preventing Transmission of Covid-19 in Indonesia. Jurnal Administrasi Kesehatan Indonesia. Volume 8. Nomor 1. Halaman 4-14. https://e-

journal.unair.ac.id/JAKI/article/view/18541. Diunduh tanggal 2 Desember 2020. 